\title{
HUMAN CAPITAL AND ITS INFLUENCE ON THE E-READINESS OF THE COMPANY: AN EMPIRICAL CASE
}

\author{
O CAPITAL HUMANO E A SUA INFLUÊNCIA NA PRONTIDÃO ELETRÓNICA DA \\ EMPRESA: UM CASO EMPÍRICO
}

\section{EL CAPITAL HUMANO Y SU INFLUENCIA EN LA PREPARACIÓN TECNOLÓGICA DE LA EMPRESA: UN CASO EMPÍRICO}

Martha Ríos-Manríquez ${ }^{1}$

\section{Cite as - American Psychological Association (APA)}

Ríos-Manríquez, M. (2021, Jan./Apr.). Human capital and its influence on the e-readiness of the company: an empirical case. International Journal of Innovation - IJI, São Paulo, 9(1), 79-107.

https://doi.org/10.5585/iji.v9i1.18246.

\begin{abstract}
Objective of the study: This article has two objectives, first to analyze how is the degree of e-Readiness on micro, small and medium enterprises (eRLMSMEs) of the state of Guanajuato, in Mexico, influenced by the technological preparation of human capital, ICT accessibility, the empowerment granted to human capital, the size and sector. The second objective is to analyze, by size and sector, which are the most relevant variables considered by the owners or managers in their e-Readiness (ER).

Methodology/approach: With a sample of 182 MSMEs, a quantitative, descriptive, correlational, discriminant and linear regression analysis was performed, using the Ordinary Least Squares Method (OLS).

Originality/Relevance: The study is relevant because it addresses the influence of human capital empowerment, e-Readiness and access to ICTs by companies in the ER of MSMEs, deepening the analysis by sector, industry, trade and services, and by size of micro, small and medium enterprises.

Main results: It was determined that all the independent variables are relevant to explain eRLMSMEs. By size, the Human Capital e-Readiness, ICT Accessibility, and Human Capital Empowerment variables are significant only for small enterprises, whereas ER of human capital substantially influences industries, commercial and service companies.

Theoretical/methodological contributions: This research goes deeper into the variables that influence the degree of $e$-Readiness on MSMEs in Mexico, considering the influence of the size and sector in their technological preparation.

Social/management contributions: The ICT are considered a necessary technological innovation for the development of MSMEs, as well as the other variables dealt with in this research, which promote changes in the context of the adoption of technological innovation.
\end{abstract}

Keywords: E-readiness of MSMEs. E-readiness of human capital. Empowerment.

\section{Resumo}

Objetivo do estudo: Este artigo tem dois objetivos, primeiro analisar como é que o grau de e-Readiness nas micro, pequenas e médias empresas (eRLMSMEs) do estado de Guanajuato, no México, é

\footnotetext{
${ }^{1} \mathrm{PhD}$. in Accounting and Auditing. University of Guanajuato - UGTO. Celaya, Guanajuato, Mexico. martha@ugto.mx
} 
influenciado pelo preparação tecnológica do capital humano, acessibilidade nas TIC, empoderamento concedido ao capital humano, a dimensão e o sector. O segundo objetivo é analisar, por dimensão e sector, quais são as variáveis mais relevantes consideradas pelos proprietários ou gestores na sua eReadiness (ER)

Metodologia/abordagem: Com uma amostra de 182 MPMEs, foi realizada uma análise quantitativa, descritiva, correlativa, discriminante e de regressão linear, usando o Método dos Mínimos Quadrados Ordinários (OLS).

Originalidade/Relevância: $\mathrm{O}$ estudo é relevante, porque aborda a influência da capacitação do capital humano, e-Readiness, e o acesso às TIC pelas empresas nas ER das MPMEs, aprofundando a análise por sector, indústria, comércio e serviços, e por dimensão das micro, pequenas e médias empresas.

Principais resultados: Foi determinado que todas as variáveis independentes são relevantes para explicar nas ER das MPMEs. Por dimensão, todas as variáveis são significativas apenas para as pequenas empresas. A ER do capital humano influenciam significativamente as indústrias, comerciais e serviços empresas.

Contribuições teóricas/metodológicas: Esta investigação vai mais fundo nas variáveis que influenciam o grau de e-Readiness nas MPMEs no México, considerando a influência da dimensão e do sector na sua preparação tecnológica.

Contribuições sociais/para a gestão: As TIC são consideradas uma inovação tecnológica necessária para o desenvolvimento das MPMEs, bem como as outras variáveis tratadas nesta investigação promovem mudanças no contexto da adoção da inovação tecnológica.

Palavras-chave: E-readição das MPMEs. E-readiness do capital humano. Empoderamento.

\section{Resumen}

Objetivo del estudio: Este artículo tiene dos objetivos, el primero analizar si el grado de preparación de las micro, pequeñas y medianas empresas (GPTMipymes) del estado de Guanajuato, está influenciado por la preparación tecnológica del capital humano, la accesibilidad a las TIC, el empoderamiento del capital humano, el tamaño y el sector. El segundo objetivo es analizar, por tamaño y sector, cuáles son las variables más relevantes consideradas por los propietarios o administradores en su preparación tecnológica (PT).

Metodología/enfoque: Con una muestra de 182 Mipymes, se realizó un estudio cuantitativo, descriptivo, correlacional, análisis discriminante y de regresión lineal, utilizando el Método de Mínimos Cuadrados ordinarios (MCO).

Originalidad/Relevancia: El estudio es relevante porque aborda la influencia que tiene el empoderamiento del capital humano, su preparación tecnológica y el acceso a las TIC que les otorga empresa en el GPT de las Mipymes, profundizando en el análisis por sector, la industria, comercio y servicios, y por tamaño de las micro, pequeñas y medianas empresas.

Principales resultados: Se determino que todas las variables independientes son relevantes para explicar el GPTMipymes. Por tamaño todas las variables son significativas únicamente para las pequeñas empresas. La PT del capital humano influyen significativamente en las industrias, empresas comerciales y servicios.

Contribuciones teóricas/metodológicas: Esta investigación profundiza en las variables que influyen en el grado de preparación tecnológica en las Mipymes de México, considerando que el tamaño y el sector influyen en su preparación tecnológica.

Aportes sociales/de gestión: Las TIC son consideradas una innovación tecnológica necesarias para el desarrollo de las Mipymes, así como las demás variables tratadas en esta investigación promueven cambios en el contexto de la adopción de la innovación tecnológica.

Palabras-clave: Grado de preparación tecnológica de las Mipymes. Preparación tecnológica del capital humano. Empoderamiento. 


\section{Introduction}

MSMEs owners and managers around the world have to consider new ways to face the challenges presented by the market, since the quality and ability to do business, which were previously enough, are now insufficient for successful market competition, and require expanding their competitive capacity by searching for tools to develop business strategy. In this context, Information and Communication Technologies (ICT), such as incorporating email accounts, website, information storage, software for management, purchase of products and services online, electronic banking, electronic commerce, integral systems, networks with a central server, among other IT (Ríos, 2017; Ríos- Manríquez, 2019), acquire a significant relevance (Fonseca, 2013), are used by the company's human capital.

Human capital is an intellectual resource, as well as a source of skills and attitudes, that contributes on a daily basis to the operation of companies. Therefore, entrepreneurs or managers need to give their collaborators the skills, knowledge, and tools that allow them to create a synergistic environment for both the organization and themselves (Srivastava and Madan, 2018), since a successful execution of business strategies demands trained people for implementation (Gupta and Gupta, 2012). That is why it is important to train the staff for ereadiness and empower them, as this allows human capital to grow, compete, and confidently face the challenges in today's globalized world, obtaining optimal performance for the organization.

In addition to empowering employees, preparing them to handle ICT, accessibility to ICT must also be provided to them, as they are necessary tools for collaborators to carry out their activities successfully.

This research justifies the fact that the technological preparation of companies today is becoming essential for business survival. However, incorporating ICT is not easy for MSMEs, due to their shortcomings in obtaining and managing resources, requiring technological preparation of human capital, facilitating accessibility in ICT and transferring decision making power to the company's Human Capital, through the empowerment strategy. In the literature, there are few studies on ICT accessibility (Martelo, Jiménez \& Jaimes, 2017), with no studies found to link the empowerment of human capital as an influencing factor in the degree of eReadiness, technological preparation of human capital and ICT accessibility. In addition, the degree of ICT readiness is an area that deserves further investigation, in accordance with what is established by Golding, Donaldson, Tennat and Black (2008), especially since the use of ICT 
is reflected in the company size and sector, and there is a tendency to increase the use of ICT as their size increases (Pérez, Ramírez, and Topete, 2017).

Therefore, this article has two objectives, first to analyze how is the degree of eReadiness on micro, small and medium enterprises (eRLMSMEs) of the state of Guanajuato, in Mexico, influenced by the technological preparation to human capital, ICT accessibility, the empowerment granted to human capital, and the company's size and sector.

The second objective is to analyze, by size and sector, which are the most relevant variables that the owners or managers consider in their ER. For this purpose, a mathematical model is proposed, using the Ordinary Least Squares Method to find the line of best fit between the variables proposed.

This article is structured in five sections: firstly the introduction which provides an overview of this study, as well as the justification, and objectives of the research. Secondly, a theoretical framework is included, on which this research is based, incorporating definitions of variables such as e-Readiness Level, technological preparation of human capital, ICT accessibility and human capital empowerment. In the third section, the methodology followed in this study is presented. In the fourth section, the results are analyzed from the perspective of the hypotheses presented, and finally, the analysis, discussion, conclusions, limitations, and future lines of research are reflected.

\section{Background}

This section reflects the literature review on the importance of human capital in the development of the degree of e-Readiness preparation of micro, small and medium-sized companies in the state of Guanajuato, Mexico, establishing the variables of this study and the research hypotheses.

\subsection{E-readiness level and human capital e-readiness}

MSMEs are obliged to seek alternatives so as not to be left out of the market, where one of the strategies of survival in the market is to adhere to technological innovations such as Information and Communication Technologies (ICT), which includes the incorporations of email accounts, website, storage of information, software for management, purchase products and services online, electronic banking, e-commerce, integral systems, networks with central server TI (Ríos, 2017; Ríos- Manríquez, 2019), among others. 
Besides, technological innovation acquires relevance by virtue of its potential to promote changes in the context in which it is implemented (Garzón, 2015; García et al., 2017), especially Information and Communication Technologies, which have positively impacted on people's lives (Rohayani, Kurniabudi, and Sharipuddin, 2015), and changed the way activities are carried out in companies (Roblizo and Cózar, 2015). By increasing the development of human capital, the value of technological preparation is highlighted.

ER is defined as the ability to absorb knowledge and understand the benefits of using the ICT (Martín, Cristescu, Ciovica and Ciovica, 2012), whether they are individuals, countries or companies (Aboelmaged, 2014), and is a facilitator to use ICT (Santiago, 2014) in the company, developing communication channels, commercialization and distribution of goods and services (Martín et al., 2012).

ICT Technological Preparation in MSMEs can be defined as the skills acquired by MSMEs to adopt, benefit, and use ICT successfully. ICT are essential tools to carry out activities efficiently and effectively, under three premises: 1) preparing technologically, 2) adaptation of ICT technologies, and 3) exploiting them and benefiting from them.

There are numerous investigations regarding technological preparation, without being a unified criterion for its evaluation (Bui, Sankaran and Sebastian, 2003; Dada, 2006; Farias, Façanha, and Brazil, 2014; Mohitmafi and Hanafizadeh, 2016; Penz, Costa, Nascimento, and Rossetto 2017; Princely, 2005; Sang and Wan, 2010; Vieira and Bins 2005).

From the literature, it is possible to find several proposals that measure the degree or level of technological preparation (ER), which can be determined through various indicators, among which are telecommunications infrastructure, electronic commerce, electronic business, human resources, business resources, technological resources, commitment, administration of Information and Communication Technologies (ICT), market forces for e-Readiness preparation, government technological preparation, and support institutions for technological preparation (Molla y Liker, 2005; Ríos, Ferrer and Contreras, 2012) or by stages of digital readiness (Fundetec, 2014; Slusarczyk, Pozo and Perurena, 2015; Ríos, 2017; Ríos- Manríquez, 2019; Slusarczyk, Pozo and Perurena, 2015; Fathian, Akhavan and Hoorali 2008), see Table 1.

Also, the introduction of ICT into organizations is currently a prevailing situation (Gimeno, 2006) and as a means of achieving competitiveness, for which reason it becomes crucial that human capital has the necessary skills to deploy its potential from the technology (Ríos, 2016; Palomo, Hernández, Pedraza and Bolaños, 2009; Molla and Liker, 2005). 
Also, if the talent of the organization has a high degree of technological preparation, it enables the organization to reach its optimal levels of efficiency and respond skillfully to the challenges that globalization inevitably presents (Ríos, 2014).

Table 1 - Methodologies to measure the e-Readiness (ER) in companies

\begin{tabular}{|c|c|c|}
\hline $\begin{array}{c}\text { ER Level } \\
\text { (Stage /level) }\end{array}$ & Description & Reference \\
\hline Basic Stage & $\begin{array}{l}\text { The company has a landline and mobile phone, website, } \\
\text { interactive website, corporate intranet, and social networks. }\end{array}$ & \multirow{3}{*}{$\begin{array}{l}\text { Ríos (2017); Ríos- } \\
\text { Manríquez (2019) }\end{array}$} \\
\hline Growth Stage & $\begin{array}{l}\text { The company has passed the basic stage, plus has storage of } \\
\text { information, software for management, purchase products } \\
\text { and services online, does electronic banking, electronic } \\
\text { invoicing and electronic commerce. }\end{array}$ & \\
\hline Maturity Stage & $\begin{array}{l}\text { The company surpasses the stage in development; it has } \\
\text { integral systems, design through software, networks with the } \\
\text { central server. }\end{array}$ & \\
\hline First stage & The company does not have ICT Access & \multirow{4}{*}{$\begin{array}{l}\text { Slusarczyk, Pozo \& } \\
\text { Perurena (2015) }\end{array}$} \\
\hline Second stage & Uses computers with internet, website and basic software. & \\
\hline Third stage & Works using a network, has complex systems. & \\
\hline Fourth stage & Has specialized systems such as ERP, CRM in all areas. & \\
\hline First Level & $\begin{array}{l}\text { The company has basic infrastructure, mobile telephony, } \\
\text { computer, and internet. }\end{array}$ & \multirow{3}{*}{ Fundetec, 2014} \\
\hline Second Level & $\begin{array}{l}\text { The company has internet, a website, and a relationship with } \\
\text { online business partners. }\end{array}$ & \\
\hline Third Level & $\begin{array}{l}\text { The company uses ICT to have smart businesses and manage } \\
\text { knowledge. }\end{array}$ & \\
\hline Basic communications & The company has landlines, mobile phones, and fax. & \multirow{4}{*}{ Kotelnikov (2007) } \\
\hline $\begin{array}{l}\text { Basic Informatic } \\
\text { Technology }\end{array}$ & $\begin{array}{l}\text { The company has computers connected to a printer with basic } \\
\text { software and hardware. }\end{array}$ & \\
\hline $\begin{array}{l}\text { Advance } \\
\text { communications }\end{array}$ & $\begin{array}{l}\text { The company has internet browsing, use of e-mail, web } \\
\text { pages, e-commerce, videoconferencing, intranet, and voice } \\
\text { over the internet. }\end{array}$ & \\
\hline $\begin{array}{l}\text { Advanced Information } \\
\text { technology }\end{array}$ & $\begin{array}{l}\text { The company has computers with advanced software with } \\
\text { business applications. }\end{array}$ & \\
\hline ER initialization & ER towards the internal of the organization & \multirow{2}{*}{$\begin{array}{l}\text { Molla y Liker (2005), } \\
\text { used by Ríos, Ferrer y } \\
\text { Contreras (2012); } \\
\text { Fathian, Akhavan \& } \\
\text { Hoorali, (2008); and } \\
\text { Ríos (2016). }\end{array}$} \\
\hline ER Institutionalization & $\begin{array}{l}\text { The company Technological Preparation in the external } \\
\text { environment }\end{array}$ & \\
\hline
\end{tabular}

Source: Elaborated based on Ríos-Manríquez (2019, p. 111).

Therefore, human capital is the essential element in this digitalization process; that is, it is important to have technological preparation in the use of computers, unlimited access to computers, unlimited access to the Internet, to provide opportunities for growth in ICT, and above all, that the company has the necessary technical and managerial skills for the use of information technologies, facilitating access to ICT. 


\subsection{ICT accessibly}

Companies increasingly require the use of ICTs because of the benefits that allow them to successfully compete with other organizations (Daghighi, Sadegh, and Ebrahimi, 2014). Therefore, the accessibility of ICT implies that all the technological resources are available to all members of the organization (Guenaga, Barbier, and Eguiluz, 2007). The ICT Accessibility "is the ability of a person to perceive, use, navigate, communicate and interact with the ICT facilities in companies", (Daniel, Udoaku and Chima, 2014, p. 30). Tiwari, Chakravarty and Goyal (2014), have defined ICT accessibility as the timely availability of the ICTs by human capital at the time they are needed.

Therefore, the successful adoption of ICTs depends on its accessibility (Pedraza, Sánchez, and García, 2005).

Thus, in this research the following indicators were considered: access to computers, access to computers with internet, and access to networked computers; as per in the studies of Molla y Liker (2005) and Ríos, Ferrer and Contreras (2012).

\subsection{Human capital and empowerment}

In the degree of technological preparation, it is not enough to only technologically prepare human capital and provide access to ICT, but also necessary to grant it empowerment, a strategy that goes beyond a business management policy, and cares about and attends to cognitive aspects of human capital, such as meaning, competence, self-determination and impact (Spreitzer,1995; Ríos, Téllez, and Ferrer, 2010).

The concept of empowerment is related to transferring decision-making power to the company's Human Capital -also called human talent based on their job position, and influences their confidence to carry out their activities (Altaf and Shahzad, 2018; Pérez and Guerrero, 2012; Ríos, Téllez, and Ferrer, 2010; Srividya, 2016).

A significant characteristic of empowerment is the great communication between the different hierarchical levels (Sulistyo and Siyamtinah, 2016). In empowerment, the concept of power is approached not from the perspective of control and dominance, but from an exchange that expands through the business network (Page and Czuba, 2011; Torres, 2011), enabling the organization to respond to changes in the environment, which translates into flexible organizations (Srividya, 2016; Sulistyo and Siyamtinah, 2016).

Empowerment of human capital is a significant challenge for any organization, and the effort invested in achieving this is effectively paid off, since the collaborator feels responsible 
and increases his degree of involvement (Srividya, 2016; Cálix, Martínez, Vigier and Núñez, 2017), allowing human capital to internalize organizational philosophy (Fong and Snape, 2013; Mallak and Kurstedt, 1996), becoming a practice of human resources that generates added value to the company (Cálix et al. 2017; Srivastava and Madan, 2018).

Empowerment positively influences employee participation, job satisfaction, organizational commitment, motivation, and job performance. It also helps to create an environment of appropriate recognition and reward, thereby improving the organization's effectiveness in achieving its objectives (Gupta and Gupta, 2012: Srividya, 2016; Valencia, 2000), manifesting itself as an element of interest for management (Frymier, Shulman, \& Houser, 1996; Gupta \& Gupta, 2012).

Empowerment can be approached from the psychological aspect of human capital, which is made up of four dimensions: meaning, self-determination, competence and impact (Spreitzer, 1995), which have been considered in the studies of Avolio, Zhu, Koh and Bhatia (2004); Cheasakul and Varma (2016); Liden, Wayne, and Sparrowe (2000) OrgambídezRamos, Moura and de Almeida (2017); Muduli (2017) Pérez and Guerrero (2012) Rico, Peinado, Salvador, and González, (2016); Ríos, Téllez, and Ferrer (2010); Seirert, Silvert and Randolph (2004); Thomas and Velthouse (1990); Zhang and Bartol (2010).

Meaning. This is how workers appropriate organizational objectives as part of their personal goals (Pérez and Guerrero, 2012; Spreitzer, 1996; Thomas and Velthouse, 1990), and organizational goals, and adapt their behavior towards the achievement of the organization's objectives (Muduli, 2017; Spreitzer, 1995).

Competence. This term represents how the workers perceived their ability to perform in their job (Orgambídez-Ramos et al. 2017; Spreitzer, 1996).

Self-determination. Manifests the autonomy that a worker has to carry out a task from start to finish (Ahearne, Mathieu, and Rapp, 2005; Spreitzer, 1996).

Impact. The degree of awareness that a worker experiences on how his actions influence the results (Avolio et al. 2004; Spreitzer, 1996; Thomas and Velthouse, 1990).

Based on the literature, the following hypotheses is proposed:

$\mathrm{H}_{1}$. The degree of e-Readiness of MSMEs in the state of Guanajuato, in Mexico, is influenced by the technological preparation of human capital, ICT accessibility and empowerment of human capital, size, and sector. 


\subsection{Company size and sector}

MSMEs around the world have shown to have a crucial role in the development, and economic growth of nations (World Bank, 2016) and Mexico is not an exception, since more than $98 \%$ of companies are of this type and provide $72 \%$ of jobs, having a $52 \%$ contribution to the Gross Domestic Product (National Commission for the Efficient Use of Energy, 2017).

In spite of the vital role they play in the economy, MSMEs present great challenges to stay competitive (Proméxico, 2014), so understanding how they perform and grow is essential to improve their development in the business world.

Assuming that all companies benefit in the same way from the ICT adoption would imply avoiding the companies' own differences (Pérez et al. 2017).

For instance, even if MSMEs are usually characterized by their flexibility, which in many cases allows them to adapt easily to market changes, this is not necessarily true when it comes to ICTs, since it has a reduced capacity to cope with abrupt or disruptive technological changes (García et al. 2017).

Without pretending to analyze why such differences exist, many studies show that there are differences in the adoption of ICT related to the size of the company and the sector to which it belongs (Constante and Quintana, 2014; Demuner, Nava and Gómez, 2014; Esparza, Navarrete and Sansores, 2012; Mendoza, 2018; Qureshi, et al. 2014; Pérez, Ramírez and Topete, 2017; Palacios, Flores-Roux and García, 2013; Ríos, 2016.

Based on the literature, the following hypotheses are proposed:

$\mathrm{H}_{2}$. The technological preparation of human capital, ICT accessibility, the empowerment of human capital, size and sector influence the degree of technological preparation (ER) of micro, small and medium enterprises in the state of Guanajuato.

$\mathrm{H}_{3}$. The degree of e-Readiness of the industrial, commercial, and service companies of the state of Guanajuato are influenced by the technological preparation of human capital, ICT accessibility and empowerment of human capital.

\section{Methodology}

In this section, the sample design, variables and indicators discussed in this study, as well as the statistical analysis used and the reliability of the instrument, are presented. This is in order to determine if the variables human capital e-Readiness, ICT accessibility, and empowerment of human capital, influence the degree of technological preparation of MSMEs. 
In this section, the sample design, variables, indicators discussed in this study, the statistical analysis used, and the reliability of the instrument are presented.

\subsection{Type of analysis}

Consequently, to specify the characteristics of the sample, the items, and the variables proposed in this study, a quantitative, descriptive, correlational study and discriminant analysis were carried out. A linear regression model, using the Ordinary Least Squares Method (OLS), was proposed to perform a cross-section analysis as it provides the Best Linear Unbiased Estimators (BLUE) under the following assumptions: 1) The model is linear in the parameters; 2) Normality, $\varepsilon_{i j} \mathrm{~N}\left(0, \sigma^{2}\right)$; 3) Homoscedasticity $\mathrm{VAK} \varepsilon_{\mathrm{ij}} \mathrm{j}=\sigma^{2}$; 4) The model is correctly specified; 5) There is no perfect multicollinearity.

\subsection{Sample}

The sample is made up of $46.7 \%$ micro, $45.6 \%$ small, and $7.7 \%$ medium-sized companies, out of a total of 182 MSMEs in the state of Guanajuato, Mexico. Also, observing in Table 2, is the sample by economic activity sector in which $57.7 \%$ are companies in the trade sector, followed by service companies $(23.6 \%)$, and industry $(18.7 \%)$.

Table 2 - Sample per sector and size

\begin{tabular}{lcccc}
\hline \multicolumn{5}{c}{$\begin{array}{c}\text { Sector of Economic Activity } \\
(\%)\end{array}$} \\
\cline { 2 - 4 } Size & Industry & Trade & Services & Total \\
\hline Micro & 3.3 & 34.6 & 8.8 & 46.7 \\
Small & 12.6 & 19.8 & 13.2 & 45.6 \\
Medium & 2.7 & 3.3 & 1.6 & 7.7 \\
Total & 18.7 & 57.7 & 23.6 & 100.0 \\
\hline Source: Own elaboration
\end{tabular}

\subsection{Instrument and reliability analysis}

The instrument used in this research is the product of different authors. The e-Readiness level items, human capital e-Readiness and ICT accessibility were adapted from the instruments of Ríos-Manríquez (2019); Ríos (2017); Ríos (2016); Slusarczyk, Pozo and Perurena (2015); Fundetec (2014), Ríos, Ferrer, and Contreras, (2012); Fathian, Akhavan, and Hoorali (2008); Kotelnikov (2007); and Molla and Liker (2005). For the psychological empowerment items, 
the one elaborated by Ríos, Téllez, and Ferrer (2010), modified and adapted to the Spanish context of Spreitzer (1995), see Table 3.

Table 3 - Variables and indicators

\begin{tabular}{|c|c|c|c|}
\hline $\begin{array}{c}\text { Variables /code } \\
\text { (Reference) }\end{array}$ & Indicators & Item & Code \\
\hline \multirow{4}{*}{$\begin{array}{l}\text { e-Readiness Level/eRL } \\
\text { (Elaborated based on Ríos, } \\
\text { 2017; Ríos- Manríquez, } \\
\text { 2019). }\end{array}$} & Early Stage & $\begin{array}{l}\text { The company has a landline and mobile phone, is } \\
\text { not connected to the internet and has no e-mail } \\
\text { account. }\end{array}$ & ES \\
\hline & Basic Stage & $\begin{array}{l}\text { The company has overcome the early stage and } \\
\text { incorporated e-mail accounts and a website. }\end{array}$ & BS \\
\hline & Growth stage & $\begin{array}{l}\text { The company has passed the basic stage, plus has } \\
\text { storage of information, software for management, } \\
\text { purchase products and services online, does } \\
\text { electronic banking and electronic invoicing }\end{array}$ & GS \\
\hline & Maturity stage & $\begin{array}{l}\text { The company surpasses the stage in development } \\
\text { and conducts e- commerce. }\end{array}$ & MS \\
\hline \multirow{5}{*}{$\begin{array}{l}\text { Human Capital e-Readiness / } \\
\text { HCER } \\
\text { (Ríos, Ferrer, and Contreras, } \\
2012 \text { and Molla and Liker, } \\
2005 \text { ). }\end{array}$} & \multicolumn{2}{|c|}{ Preparation for the use of computers } & PUC \\
\hline & \multicolumn{2}{|c|}{ Unlimited access to computers } & $\mathrm{UAC}$ \\
\hline & \multicolumn{2}{|c|}{ Unlimited internet access } & UIA \\
\hline & \multicolumn{2}{|c|}{ IT growth opportunities } & ITGO \\
\hline & \multicolumn{2}{|c|}{ Technical, management and other knowledge for the use of IT } & TMyK \\
\hline \multirow{3}{*}{$\begin{array}{l}\text { ICT Accessibility/ICTAcc } \\
\text { (Spreitzer, 1995; Ríos, Téllez, } \\
\text { and Ferrer, 2010). }\end{array}$} & \multicolumn{2}{|c|}{ Percentage of employees with a computer } & PEC \\
\hline & \multicolumn{2}{|c|}{ Percentage of computers with Internet access } & PCI \\
\hline & \multicolumn{2}{|c|}{ Percentage of networked computers } & $\mathrm{PNC}$ \\
\hline \multirow{12}{*}{$\begin{array}{l}\text { Human Capital } \\
\text { Empowerment / HCEMP } \\
\text { (Spreitzer, 1995; Ríos, Téllez, } \\
\text { and Ferrer; 2010). }\end{array}$} & \multirow{3}{*}{ Significance } & Importance of the work of $\mathrm{HC}$ & SIG \\
\hline & & Activities of $\mathrm{HC}$ & \\
\hline & & Performance of $\mathrm{HC}$ & \\
\hline & \multirow{3}{*}{ Capacity } & Capacity of HC & CAP \\
\hline & & Knowledge and skills of $\mathrm{HC}$ & \\
\hline & & Abilities of $\mathrm{HC}$ & \\
\hline & \multirow{3}{*}{$\begin{array}{l}\text { Self- } \\
\text { determination }\end{array}$} & Autonomy of $\mathrm{HC}$ & SD \\
\hline & & Decision of $\mathrm{HC}$ & \\
\hline & & Independence and freedom of $\mathrm{HC}$ & \\
\hline & \multirow{3}{*}{$\begin{array}{l}\text { Impact on } \\
\text { Results }\end{array}$} & Initiative of $\mathrm{HC}$ & IMP \\
\hline & & Control of HC & \\
\hline & & Influence of $\mathrm{HC}$ & \\
\hline \multicolumn{4}{|l|}{ Company characteristics } \\
\hline \multirow{3}{*}{$\begin{array}{l}\text { Company Size / CS } \\
\text { (DOF, 2009). }\end{array}$} & Micro & 5 to 10 workers & \\
\hline & Small & 11 to 50 workers & \\
\hline & Medium & 51 to 250 workers & \\
\hline \multirow{3}{*}{$\begin{array}{l}\text { Economic Activity Sector / } \\
\text { ECAS } \\
\text { (DOF, 2009). }\end{array}$} & \multicolumn{3}{|l|}{ Industry } \\
\hline & \multicolumn{3}{|l|}{ Trade } \\
\hline & \multicolumn{3}{|l|}{ Services } \\
\hline
\end{tabular}

Source: Own elaboration. 
In this paper, 27 items were analyzed: 5 on the preparation of human capital in ICT; 3 about ICT accessibility; 7 of technological readiness degree in MSMEs; and 12 about empowerment. All variables were at 6 point of the Likert scale. Using Cronbach's Alpha, the reliability of the instrument was obtained of $\alpha=0.700$, considered as adequate (George and Mallery, 2003; Hair, Anderson, Tatham, y Black, 2014). By variable, empowerment is the variable with the highest internal consistency (see Table 4).

Table 4 - Internal consistency of the instrument using Cronbach's

\begin{tabular}{l|c|c}
\multicolumn{2}{c}{ Alpha } \\
\hline Variable & $\begin{array}{c}\text { \# of } \\
\text { elements }\end{array}$ & $\begin{array}{c}\text { Cronbach's } \\
\text { Alpha }\end{array}$ \\
\hline eRL & 7 & .728 \\
ICTAcc & 3 & .721 \\
HCER & 5 & .823 \\
HCEMP & 12 & .910 \\
Total & 27 & .700 \\
\hline
\end{tabular}

Source: Own elaboration.

\subsection{Proposed model}

The objective of this research is to analyze whether the technological preparation, ICT accessibility and empowerment granted to human capital, influence the degree of technological preparation of micro, small and medium-sized companies in the state of Guanajuato, Mexico. For this, two equations are expressed, the first under the assumption that size and sector influence the eRL MSMEs:

$$
e R L M S M E s_{i}=\beta_{0}+\beta_{1} \text { HCER }_{i}+\beta_{2} \text { ICTACC }_{i}+\beta_{3} \text { HCEMP }_{i}+\beta_{4} \text { ECAS }_{i}+\beta_{5} \text { CS }_{i}+\varepsilon_{i}
$$

Once the influence of size and sector is established, the second equation is:

$$
\text { eRLMSMEs } s_{i}=\beta_{0}+\beta_{1} \text { HCER }_{i}+\beta_{2} \text { ICTACc }_{i}+\beta_{3} H_{C E M P_{i}}+\varepsilon_{i}
$$

Where:

eRLMSMEs $s_{i}=$ e-Readiness Level of micro, small and medium-sized companies.

$\mathrm{HCER}_{\mathrm{i}}=$ Human Capital e-Readiness

ICTAcc $_{\mathrm{i}}=$ ICT Accessibility

HCEMP $_{i}=$ Human Capital Empowerment

$\mathrm{ECAS}_{\mathrm{i}}=$ Sector of economic activity

$\mathrm{CS}_{\mathrm{i}}=$ Company Size

$\varepsilon_{\mathrm{i}}=$ Random error 


\section{Analysis of results}

Based on the hypotheses raised in this research, the analysis is carried out from the perspective of the MSMEs manager, and whether they consider that development in technological preparation is important to empower their human capital, prepare them technologically and provide them with ICT accessibility.

A descriptive analysis of the variables proposed in this study is carried out, starting with the Level of e-Readiness of MSMEs in the state of Guanajuato, Mexico, where $41.2 \%$ are in a state of maturity, followed by $36.8 \%$ in the initial stage, $14.8 \%$ in basic stage, and $7.1 \%$ in the growth stage. Each sector of economic activity, industry and service (11\% respectively), is mostly in the maturity stage, while service companies are the ones that are mostly in the initial stage $(25.3 \%)$. Going further by size, it is the small companies that are predominantly in the maturity stage (20.9\%), and the micro-companies are mostly in the initial stage $(21.40 \%)$ (see Table 5).

Table 5 - Descriptive statistics of the e-Readiness of MSMEs in the state of Guanajuato

\begin{tabular}{l|l|r|r|r|r|r}
\hline $\begin{array}{l}\text { Sector of } \\
\text { economic activity }\end{array}$ & company & \multicolumn{4}{|c|}{ e-RLMSMEs (\%) } & \multirow{2}{*}{ Total } \\
\cline { 2 - 6 } & size & Early Stage & Basic Stage & Growth stage & Maturity stage & \\
\hline & Micro & 1.1 & 0.0 & 0.0 & 2.2 & 3.3 \\
& Small & 2.2 & 2.2 & 1.1 & 7.1 & 12.6 \\
Industry & Medium & 0.5 & 0.0 & 0.5 & 1.6 & 2.7 \\
\hline & Total & 3.8 & 2.2 & 1.6 & 11.0 & 18.7 \\
\hline & Micro & 16.5 & 6.6 & 2.2 & 9.3 & 34.6 \\
& Small & 8.2 & 2.7 & 1.6 & 7.1 & 19.8 \\
Trade & Medium & 0.5 & 0.0 & 0.0 & 2.7 & 3.3 \\
\hline & Total & 25.3 & 9.3 & 3.8 & 19.2 & 57.7 \\
\hline \multirow{5}{*}{ Services } & Micro & 3.8 & 1.1 & 0.5 & 3.3 & 8.8 \\
& Small & 3.3 & 2.2 & 1.1 & 6.6 & 13.2 \\
& Medium & 0.5 & 0.0 & 0.0 & 1.1 & 1.6 \\
& Total & 7.7 & 3.3 & 1.6 & 11.0 & 23.6 \\
\hline \multirow{3}{*}{ Total } & Micro & 21.4 & 7.7 & 2.7 & 14.8 & 46.7 \\
& Small & 13.7 & 7.1 & 3.8 & 20.9 & 45.6 \\
& Medium & 1.6 & 0.0 & 0.5 & 5.5 & 7.7 \\
& Total & 36.8 & 14.8 & 7.1 & 41.2 & 100.0 \\
\hline
\end{tabular}

Source: Own elaboration.

In relation to the association between the variables in Table 6 , it is observed that the eRL of the MSMEs in the state of Guanajuato is positively and significantly related to the Technological Preparation of Human Capital $r=0.819$, ICT accessibility $r=0.676$ and Size $\mathrm{r}=0.241$, all at levels of $\rho<0.01$. 
Table 6 - Association between the eRLMSMEs and the HCEMP, FLIN, HCER, ICTAcc, $\mathrm{CS}$, and ECAS

\begin{tabular}{|l|c|c|c|c|c|c|}
\hline & I & II & III & IV & V & VI \\
\hline eRLMSMEs (I) & 1 & & & & & \\
\hline HCER (II) & $.819^{* *}$ & 1 & & & & \\
\hline ICTAcc (III) & $.676^{* *}$ & $.621^{* *}$ & 1 & & & \\
\hline HCEMP (IV) & .128 & $.360^{* *}$ & -.083 & 1 & & \\
\hline CS (V) & $.241^{* *}$ & $.171^{*}$ & $.199^{* *}$ & -.073 & 1 & \\
\hline ECAS (VI) & -.080 & -.042 & -.033 & .011 & -.115 & 1 \\
\hline
\end{tabular}

Note: One and two asterisks indicate significance levels of $5 \%$ and $1 \%$, respectively.

Source: Own elaboration.

Subsequently, a discriminant analysis was carried out to describe whether there are differences between categorical groups defined in the research (Fontalvo, De la Hoz, and Vergara, 2012; Figueras, 2000; Fisher, 1936), in order to compare and describe the means of the variables studied, considering an analysis of ANOVA and multivariate significance. Table 7 contrasts the equality of group means for the variables of the model, pointing out that in companies the most important dimensions are Human Capital e-Readiness, ICT Accessibility and size of the company. This is considered since the null hypothesis determines that the means are different if the value of the significance is less than $0.05(\mathrm{p}<0.05)$.

Table 7 - ANOVA using the variables HCEMP, HCER, ICTAcc, ECAS, and CS with eRLMSMEs

\begin{tabular}{l|c|c|c}
\hline & L. de Wilks & \multicolumn{1}{|l|}{ F } & Sig. \\
\hline HCER & .332 & 119.333 & .000 \\
ICTAcc & .504 & 58.475 & .000 \\
HCEMP & .981 & 1.148 & .331 \\
CS & .938 & 3.918 & .010 \\
ECAS & .993 & .398 & .755 \\
\hline
\end{tabular}

Source: Own elaboration.

To determine the explained variance in each of the discriminant axes, the calculation of eigenvalues and Wilks' Lambda were used. In Table 8, it is observed that three functions are established, the first of them describes $97.5 \%$ of the explained variance, with a high canonical correlation of 0.867 , indicating that some variables could be estimated to discriminate between groups adequately. 
Table 8 - Auto values of the discriminant canonical functions

\begin{tabular}{c|c|c|c|c}
\hline Function & Eigenvalue & Variance \% & $\begin{array}{c}\% \\
\text { accumulated }\end{array}$ & $\begin{array}{c}\text { Canonical } \\
\text { correlation }\end{array}$ \\
\hline 1 & $3.029^{\mathrm{a}}$ & 97.5 & 97.5 & .867 \\
2 & $.077^{\mathrm{a}}$ & 2.5 & 100.0 & .268 \\
3 & $.001^{\mathrm{a}}$ & .0 & 100.0 & .027 \\
\hline
\end{tabular}

Note: a The first 3 canonical discriminant functions have been used in the analysis. Source: Own elaboration.

Contrasting the means of the three discriminant functions in all groups, Table 9 shows the Wilks Lambda values in each function, determining an adequate significance $p<0.05$ in 1 to 3, which indicates that these functions will lead us to accept that there are behavioral differences between the group means.

Table 9 - Wilks Lambda

\begin{tabular}{c|c|c|c|c}
\hline Contrast of functions & Wilks Lambda & Chi-squared & Degree of Freedom & Sig. \\
\hline 1 to 3 & .230 & 259.248 & 15 & .000 \\
2 to 3 & .928 & 13.270 & 8 & .103 \\
3 & .999 & .126 & 3 & .989 \\
\hline
\end{tabular}

Source: Own elaboration.

Once it has been determined that there are differences between groups, the linear regression is carried out using the Ordinary Least Squares (OLS) method, under the following assumptions: that the OLS estimators behave with a normal distribution and converge in probability to the real coefficients (Greene, 2003), individual significance test ("T" test), global significance test (F test), the goodness of fit, non-autocorrelation, multicollinearity, heteroskedasticity, and specification.

In order to establish the assumption that size and sector influence the eRLMSMEs, see Table 10, the regression model warns an $\mathrm{R}^{2}$ at 0,724 , so the independent variables explain the changes in the level of technological readiness of the MSMEs in the state of Guanajuato as $72.4 \%$. The F test determined that, jointly, the independent variables considered in the model are relevant to explain the eRLMSMEs with a level of significance $\mathrm{p}<0.01$.

Verifying that there are no multicollinearity problems between the model variables, the Variance Inflation Factor (VIF) and Tolerance (TOL) tests were used. The model presents that the returners have a VIF less than 10 , as well as a TOL close to 0.1 , which indicates that there are no multicollinearity problems (Gujarati and Porter, 2010). 
To detect that the model did not have heteroskedasticity problems and verify that the estimators of the OLS model are the Best Unbiased Linear Estimators (BLUE), the homoscedasticity test was applied, using the Breusch-Pagan test observed in Table 10, indicating that within the model there is no heteroskedasticity (0.019), with a Prob $>\mathrm{c} 2=0.664$.

Performing the residual normality test, the Jarque Bera test was used, observing in Table 10 that the contrast distribution of the general model is normal (Jarque Bera $=2.61$, with a Prob $>\mathrm{c} 2=0.272)$.

The Ramsey specification test was applied to detect that the proposed model of eRLMSMEs did not have omitted independent variables and that the variables of the model are necessary to explain it. Perceiving in Table 10, in the proposed model, there are no omitted variables, so the Ramsey test (3.94, with Prob > F=0,051) supports the results of the regression analyzed, that is, that the model does not require incorporating more independent variables into the model. Thus, the Ramsey test demonstrates the acceptable functionality of the model (MGaleeva, 2019).

In relation to autocorrelation, the Durbin-Watson test (1.938) was applied, which ruled out a correlation between errors with a significance level of $1 \%$. When working with crosssectional data, it is consistent that the model does not present problems of autocorrelation.

Establishing the influence of the sector and size of the eRL in the companies in the State of Guanajuato, 6 models were established: 3 by size (micro, small and medium) and 3 by sector (industry, commerce, and service), in order to personally analyze which independent variables are the most significant to them. 
Table 10 - eRLMSMEs Model

\begin{tabular}{|l|l|l|l|l|l|l|l|}
\hline eRLMSMEs & $\begin{array}{c}\text { Model 1 } \\
\text { General }\end{array}$ & $\begin{array}{c}\text { Model 2 } \\
\text { Micro } \\
\text { Company }\end{array}$ & $\begin{array}{c}\text { Model 3 } \\
\text { Small } \\
\text { Company }\end{array}$ & $\begin{array}{c}\text { Model 4 } \\
\text { Medium } \\
\text { Company }\end{array}$ & $\begin{array}{c}\text { Model 5 } \\
\text { Industry }\end{array}$ & $\begin{array}{c}\text { Model 6 } \\
\text { Trade }\end{array}$ & $\begin{array}{c}\text { Model 7 } \\
\text { Services }\end{array}$ \\
\hline $\begin{array}{l}\text { Human Capital e- } \\
\text { Readiness }\end{array}$ & $1.947^{* * *}$ & $1.943^{* * *}$ & $1.956^{* * *}$ & $2.693^{*}$ & $2.151^{* * *}$ & $1.906^{* * *}$ & $2.021^{* * *}$ \\
\hline ICT Accessibility & $0.316^{* * *}$ & $0.207^{* *}$ & $0.420^{* * *}$ & 0.191 & 0.333 & $0.321^{* * *}$ & $0.291^{*}$ \\
\hline $\begin{array}{l}\text { Capital Human } \\
\text { Empowerment }\end{array}$ & $-0.233^{* * *}$ & -0.048 & $-0.437^{* * *}$ & -0.504 & -0.051 & $-0.231^{* *}$ & $-0.372^{* *}$ \\
\hline Sector & -0.071 & & & & & & \\
\hline Size & $0.139^{*}$ & & & & & & \\
\hline Constant & $-4.796^{* * *}$ & $-5.350^{* * *}$ & $-4.028^{* * *}$ & $-5.566^{* *}$ & $-6.385^{* * *}$ & $-4.635^{* * *}$ & $-4.175^{* * *}$ \\
\hline $\mathrm{R}^{2}$ adjusted & $\mathbf{0 . 7 2 4}$ & $\mathbf{0 . 7 1 8}$ & $\mathbf{0 . 7 3 4}$ & $\mathbf{0 . 6 1 4}$ & $\mathbf{0 . 7 2 6}$ & $\mathbf{0 . 6 7 8}$ & $\mathbf{0 . 7 4 6}$ \\
\hline F & 95.762 & 68.389 & 76.434 & 7.886 & 30.195 & 73.854 & 42.090 \\
\hline Prob > F & 0.000 & 0.000 & 0.000 & 0.001 & 0.000 & 0.000 & 0.000 \\
\hline $\begin{array}{l}\text { Kolmogorov- } \\
\text { Smirnov }\end{array}$ & & 2.99 & 1.96 & & & 6.290 & \\
\hline Prob > Z & & 0.224 & 0.374 & & & 0.074 & \\
\hline Jarque Bera & 2.61 & 0,642 & 0.607 & 0.611 & & & 0.601 \\
\hline Prob > c2 & 0.272 & 0,805 & 0.854 & 0.849 & & & 0.862 \\
\hline Shapiro Wilk & & & & -0.781 & 0.747 & & -0.214 \\
\hline Prob > c2 & & & & 0.782 & 0.228 & & 0.585 \\
\hline Breusch-Pagan & 0.019 & 0.04 & 0.020 & 2.170 & 0.190 & 0.440 & 0.090 \\
\hline Prob > c2 & 0.664 & 0.839 & 0.886 & 0.141 & 0.666 & 0.509 & 0.762 \\
\hline Ramsey Test & 3.94 & 2.45 & 1.180 & 8.010 & 2.000 & 3.37 & 2.66 \\
\hline Prob > F & 0,051 & 0,072 & 0.324 & 0.268 & 0.092 & 0.004 & 0.063 \\
\hline Durbin-Watson & $1.938^{* * *}$ & $1.801 * * *$ & $2.154^{* * *}$ & $2.363^{* *}$ & $2.335^{* * *}$ & $1.711^{* * *}$ & $2.155^{* * *}$ \\
\hline Observations & 182 & 85 & 83 & 14 & 34 & 105 & 43 \\
\hline
\end{tabular}

Note: In the normality tests, the Shapiro Wilk test was used for observations less than 50; Kolmogorov-Smirnov's for over 50 observations and Jarque Bera's for over 100 observations.

One, two and three asterisks indicate significance levels of 10,5 and $1 \%$, respectively.

Source: Own elaboration.

By size, in micro-enterprises, the independent variables that are most significant to them are ICT Accessibility and Human Capital e-Readiness. In small companies, all the variables proposed in the model are significant, while in medium-sized, the Technological Preparation of Human Capital is the most important, determining that together the predictor variables are relevant to explain the degree of technological preparation of the companies located in the state of Guanajuato (statistic $F=68.389, \rho<0.001$ micro; small $F=76.434, \rho<0.001$; medium $F=$ 7,886 with a significance level of $\rho=0.001$ ).

By sector, in the industry, the Technological Preparation of Human Capital is most significant, while that in the trade, commerce and services sector, all the variables proposed in the model are important.

Analyzing the variance, model 5 explains $72.6 \%$ of the dependent variable eRL, with models 6 and 7 clarifying $67.8 \%$ and $74.6 \%$, respectively. This reveals that the linear adjustment is high in industry and services, explaining more than $70 \%$ of the variation and is 
acceptable in commercial companies, according to Feregrino (2016), determining a significant linear relationship between the independent variables HCER, ICTAcc and HCEMP and the ERL (see statistic F and $\rho<0.001$ in Table 10).

Note that the six models pass all tests, except for trade, which show specification problems $($ Ramsey $=3.37$ with Prob $>F=0.004)$, when detecting a p-value lower than the significance level p> 0.05 (Ramsey, 1969; MGaleeva, 2019), see Table 10. In relation to the Normality Test, the tests were used according to the number of observations analyzed: Swilk for observations less than 60 , Kolmogorov-Smirnov for observations greater than 60 , and Jarque Bera for observations from 100 upwards (Thadewald \& Buning, 2007; Yazici \& Yolacan, 2007). As Observed in Table 10 the probability value is greater than 0.05 in all models, which is recommended by Díaz, Mejía, Erquizio and Ramírez (2015). The proposed models do not reveal multicollinearity problems with values lower than 10 (FIV), as well as TOL close to 1 (Gujarati and Porter, 2010). It should be noted that, in terms of error, the six models reveal the absence of autocorrelation, as per the Durbin-Watson test, with values between 1,711 and 2,363 and according to what was indicated by De la Fuente (2011) and Quintana and Mendoza (2008), which indicate values between 1,500 to 2,500 .

Regarding the hypotheses, hypothesis $\mathrm{H}_{1}$ is partially accepted since not all companies are in the maturity stage. Therefore, hypotheses $\mathrm{H}_{2}$ and $\mathrm{H}_{3}$ are accepted since both the independent variables proposed in this investigation influence the eRL of MSMEs.

\section{Discussion}

This research coincides with Srivastava and Madan (2018); and Matthews, Diaz, and Cole, (2003) that human capital should be empowered and, in addition, provide tools such as Information and Communication Technologies, according to Ríos (2016); Bocanegra and Vázquez (2010); and Molla and Liker (2005), ensuring that ICT accessibility, mentioned by Guenaga, Barbier, and Eguiluz (2007), is available to all collaborators; and Pedraza, Sánchez and García (2005) and prepare them digitally as indicated by Ríos, (2014); Miquilena and Portillo (2010) and Fathian et al. (2008).

In addition, in the study by Ríos (2017), aimed at the automotive sector of Guanajuato, Hidalgo and Querétaro, with a sample of 48 companies, it was determined that the companies of the State of Guanajuato are in the mature stage, but they do not attach importance to comprehensive systems, nor designs through software, and less than $10 \%$ use central service networks. Coinciding with this research, in the sense that although $41.2 \%$ are in the maturity 
stage, it is because MSMEs use e-commerce, but are not interested in adopting integral systems, design through software, and networks without a central server. In reference to the study by Ríos-Manríquez (2019) of 133 women entrepreneurs from the state of Guanajuato of MSMEs, only $30.8 \%$ carry out electronic commerce, where micro $(13.5 \%)$ use e-commerce the most, while in this research it is found that MSMEs e-commerce is used more by small companies $(20.6 \%)$.

These results indicate that in the MSMEs of Guanajuato in Mexico, they have a better degree of digital readiness compared to the MSMEs in Colombia, according to the study by Martelo, Jiménez and Jaimes (2017), although they have the challenge of continuing to advance in the incursion of e-commerce, as well as incorporating ICT such as integral systems, design through software, networks without a central server, specialized systems such as ERP, CRM, among others, if they intend to stay in the market and handle the economic crisis they are facing, where the challenge is to reinvent yourself to survive.

\section{Conclusions}

The objective of this research was to analyze whether the technological preparation to human capital, ICT accessibility and the empowerment granted to human capital influence in the level of e-Readiness of micro, small and medium-sized companies in the state of Guanajuato, Mexico.

Under the assumption proposed in this study, the size and sector influence the eRL of MSMEs, and later disaggregating this into three models based on size (micro, small and medium), with a further three models formed by sector (industry, commerce, and services). The results of the model were argued with the normality tests, T-test, F-test, goodness of fit, autocorrelation, multicollinearity, heteroskedasticity, and specification. Indicating that the model does not have omitted variables, determining that all independent variables are relevant to explain the eRL in MSMEs located geographically in the state of Guanajuato.

This specifies that the characteristics by size and sector of MSMEs influence the vision that the owners or managers have of the indicators proposed in the model.

By size, in micro-companies, the most relevant variables in their eRL were the human capital e-Readiness, ICT accessibility and Capital Human Empowerment. Whereby in the small companies, all the independent variables were an influence. While in the medians, human capital e-Readiness is predominantly important. 
By sector, for industrial companies, the most relevant variable is human capital eReadiness. In the trade and service sector, all the independent variables influence their eRL, from the perception of owners or managers.

Thus, it is determined that the owners, managers or entrepreneurs are a key influence in the use of ICT and therefore, in their degree of technological preparation, in accordance with the provisions of Ríos-Manríquez (2019) and Golding et al. (2008).

In this study, it is recognized that the results vary by size and sector, since they have different characteristics that affect or benefit their degree of adoption, as well as the influence of the factors proposed in this research, in agreement with what was stated by Golding, Donaldson, Tennant and Black (2008), by establishing that the attributes of MSMEs are different by size and sector.

The limitations and future lines of research of the study are: the sample, which should be expanded in medium-sized and industrial companies, in order to obtain more precise data and delve into the reasons why these type of companies consider that empowerment of human capital and ICT accessibility are not as relevant in their eRL. Another limitation is that this study was only directed at companies located in the state of Guanajuato, so it is suggested to expand the sample to all the states of Mexico, and to deepen the confirmatory statistical analysis.

Another restriction is that the model was not well specified in commercial companies, which indicates that it is necessary to delve into what other variables affect eRL, such as those proposed by Fathian, Akhavan and Hoorali (2008), Fundetec (2014), Kotelnikov (2007), Molla and Liker (2005), Ríos, Ferrer and Contreras (2012), Slusarczyk, Pozo and Perurena (2015).

The studies found in the literature are those related to the preparation of human capital as a necessary element for the technological preparation of companies (Molla and Liker, 2005; Ríos, 2016, Ríos, Ferrer and Contreras, 2012, Fathian, Akhavan and Hoorali, 2008), but not of the other variables proposed in this study as a whole. They pose the influence of the empowerment of human capital, its technological preparation, and the access to ICT that the company gives them in the eRL of the MSMEs, showing the relevance for decision-makers within MSMEs, which is considered the main contribution of this study.

This research goes deeper into the variables that influence the degree of $e$-Readiness on MSMEs in Mexico, considering the influence of the size and sector in their technological preparation. 
Concluding on the importance of undertaking analysis by sector and size, as when deep evaluation is carried out, it is verified that the owners or directors of micro, small, medium, industrial, commercial and service companies give different importance to the variables HCER, ICTAcc, HCEMP in the company's technology readiness degree.

\section{Acknowledgment}

The author acknowledges the Direction of Support for Research and Graduate Studies (DAIP), of the University of Guanajuato, for the institutional support to the project "Access and use of information and communication technologies in the empowerment of human capital", with identification number: CIIC318 / 2018.

\section{References}

Aboelmaged, M. G. (2014). Predicting e-readiness at firm-level: An analysis of technological, organizational, and environmental (TOE) effects on e-maintenance readiness in manufacturing firms. International Journal of Information Management, 34, 639-651. doi: 10.1016/j.ijinfomgt.2014.05.002 0268-4012

Ahearne, M., Mathieu, J., \& Rapp, A. (2005). To Empower or Not to Empower Your Sales Force? An Empirical Examination of the Influence of Leadership Empowerment Behavior on Customer Satisfaction and Performance. Journal of Applied Psychology, 90(5), 945955. doi:10.1037/0021-9010.90.5.945.

Altaf, M. \& Shahzad, A. (2018). "That's my job" Exploring the effect of brand empowerment towards employee brand equity: The mediating role of employee critical psychological states. Revista Brasileira de gestão de negocios, 20(4), 599-618. Recovered from https://www.academia.edu/37531288/RBGN_Thats_my_job_Exploring_the_effect_of_bra nd_empowerment_towards_employee_brand_equity_The_mediating_role_of_employee_cr itical_psychological_states.

Avolio, B., Zhu, W., Koh, W., \& Bhatia, P. (2004). Transformational leadership and organizational commitment: mediating role of psychological empowerment and moderating role of structural distance. Journal of Organizational Behavior (25), 951-968. Recovered from https://onlinelibrary.wiley.com/doi/abs/10.1002/job.283.

Banco Mundial. (2016). Banco Mundial BIRF-AIF. Los emprendedores y las pequeñas empresas impulsan el crecimiento económico y crean empleos. Recovered from http://www.bancomundial.org/es/news/feature/2016/06/20/entrepreneurs-and-smallbusinesses-spur-economic-growth-and-create-jobs.

Bocanegra, C. \& Vázquez, M. Á. (2010). El uso de tecnología como ventaja competitiva en el micro y pequeño comercio minorista en Hermosillo, Sonora. Estudios Fronterizos, nueva época, 11(22), 207-229. Recovered from http://ref.uabc.mx/ojs/index.php/ref/article/view/129/228. 
Bui, S., Sankaran, S. y Sebastian, I. M. (2003). A framework for measuring national ereadiness. Int. J. Electronic Business, 1(1), 3-22. Recovered from https://www.researchgate.net/profile/Tung_Bui2/publication/220300303_A_framework_for _measuring_national_e-readiness/links/573cd19408ae9f741b2ebeb0.pdf.

Cálix, C. G., Martínez, L. B., Vigier, H. P. \& Núñez, J. J. (2017). El Rol del Empowerment en el Éxito Empresarial. Investigación Administrativa (117). Recovered from http://www.redalyc.org/articulo.oa?id=456046142002.

Cheasakul, U. \& Varma, P. (2016). The influence of passion and empowerment on organizational citizenship behavior of teachers mediated by organizational commitment. Contaduría y Administración, 6(3), 422-440. Recovered from https://www.redalyc.org/articulo.oa?id=39546036002.

Comisión Nacional para el Uso Eficiente de la Energía (2017). El Artículo 116 de la Ley de Transición Energética. Gobierno de México. Recovered from https://www.gob.mx/conuee/acciones-y-programas/micro-pequenas-y-medianas-empresas.

Constante, L. I. \& Quintana, W. H. (2014). Alineamiento de las Tecnologías de la Información y Comunicaciones (TIC's) con la estrategia del negocio en las PYMES. Master Thesis. Quito, Ecuador: Escuela Politécnica Nacional.

Dada, D. (2006). E-readiness for developing countries: moving the focus from the environment to the users. The Electronic Journal of Information Systems in Developing Countries, 27(6), 1-14. Recovered from https://doi.org/10.1002/j.16814835.2006.tb00183.x.

Daghighi, Z., Sadegh, M. \& Ebrahimi, R. (2014). Operational indicators for measuring organizational e-readiness based on fuzzy logic: A challenge in the Agricultural Organization of Guilan Province, Iran. Information Processing in Agriculture, 115-12. Recovered from https://ac.els-cdn.com/S2214317314000225/1-s2.0-S2214317314000225main.pdf?_tid=d3451e91-cb1a-4297-a5da87a4f1ec8af2\&acdnat=1548713228_d37ee75d1db568efea9298be139671d8.

Daniel, O. C., Udoaku, O. S. \& Chima, O. D. (2014). Availability and Accessibility of ICT in the Provision of Information Resources to Undergraduate Students in Babcock University Library. Research on Humanities and Social Sciences, 4(14), 29-33.

De la Fuente, F. S. (2011). Regresión Múltiple. Facultad Ciencias Económicas y Empresariales UAM-2011. Recovered from http://www.estadistica.net/ECONOMETRIA/MULTIVARIANTE/REGRE_MULTIPLE/re gresion-multiple.pdf.

DOF (2009). Acuerdo por el que se establece la estratificación de las micro, pequeñas y medianas empresas. Diario Oficial de la Federación (DOF: 30/06/2009), SEGOB Recovered from http://dof.gob.mx/nota_detalle.php?codigo=5096849\&fecha=30/06/2009. 
Díaz, C. MA., Mejía, R. P., Erquizio, E. A. \& Ramírez, R. R. (2015). Recesión en los estados de México: magnitud y causas. Contaduría y Administración, 60(2), 147-168. https://doi.org/10.1016/j.cya.2015.05.005.

Demuner, M. R., Nava, R. M. \& Gómez, M. R. (2014). Las tecnologías de información y comunicación en las pequeñas y medianas empresas. Centro de Estudios e Investigaciones para el Desarrollo Docente (1), 1-21.

Esparza, J. L., Navarrete, J. L. \& Sansores, E. (2012). El impacto de las Tecnologías de Información y Comunicación (TIC) en la Gestión de las MiPyME en México. Recovered from http://elcriterio.com/revista/ajoica/contenidos_8/tic_gestion_mipyme_mexico_esparza

Farias, A. C., Façanha, S. \& Brasil, A. (2014). A coevolução das capacidades tecnológicas entre empresas multinacionais (MNE) e Pequenas e Médias Empresas (PME) de Tecnologia da Informação e Comunicação (TIC) em redes de tecnologia e inovação. Revista Ciências Administrativas, 20(2), 558-583. Recovered from http://www.redalyc.org/articulo.oa?id=475647147007.

Fathian, M., Akhavan, P. \& Hoorali, M. (2008). E-readiness assessment of non-profit ICT SMEs in a developing country: The case of Iran. Science Direct, 28(9), 578-590. Recovered from https://doi.org/10.1016/j.technovation.2008.02.002.

Feregrino, F. J. (2016). El modelo de regresión. En Quintana, R. L. and Mendoza, M.A. (2016). Econometría aplicada utilizando R. Universidad Nacional Autónoma de México. México.

Figueras, S. (2000): Análisis Discriminante, [online] 5campus.com, Estadística. Recovered from http://www.5campus.com/leccion/discri.

Fisher, R.A. (1936). The use of multiple measurements in taxonomic problems. Annuals of Eugenics. 7(2):179-188. Recovered from http://www.comp.tmu.ac.jp/morbier/R/Fisher1936-Ann._Eugen.pdf.

Fong, K. H. \& Snape, E. (2013). Empowering Leadership, Psychological Empowerment, and Employee Outcomes: Testing a Multi-level Mediating Model. British Journal of Management, 26, 126-138. Recovered from https://doi.org/10.1111/1467-8551.12048.

Fonseca, D. E. (2013). La prospectiva y el conocimiento de las TICs en las pymes del departamento de Boyacá (Colombia). Pensamiento \& Gestión (34), 1-20. Recovered from http://search.ebscohost.com/login.aspx $?$ direct=true $\& d b=a 9 h \& A N=91100288 \&$ site=ehostlive.

Fontalvo, H. T., De la Hoz, G, E., \& Vergara, J.C. (2012). Aplicación de análisis discriminante para evaluar el mejoramiento de los indicadores financieros en las empresas del sector alimento de Barranquilla-Colombia. Revista chilena de ingeniería, 20(3): 320330.

Frymier, A. B., Shulman, G. M. \& Houser, M. (1996). The development of a learner empowerment measure. Communication education, 45. Recovered from https://www.tandfonline.com/doi/abs/10.1080/03634529609379048. 
Fundetec (2014). Análisis sectorial de implantación de las TIC en la pyme española. Fundetec. Ministerio de Industria Energía y Turismo, re.es, ontsi. Recovered from http://www.ipyme.org/publicaciones/informe-epyme-2014.pdf.

Jarque, C. \& Bera, A. (1987). A test for normality of observations and regression residuals. International Statistical Review, 55(2), 163-172.

García, B. J., Rojas, J., Cerón, H., Guzmán, L. E., Corichi, A. \& Marín, M. M. (2017). Desarrollo de un modelo de resiliencia para la incorporación de tecnologías de información y comunicación en las pequeñas y medianas empresas del sector textil mexicano. Strategy, Technology \& Society (4), 25-49. Recovered from http://www.ijsts.org/index.php/STS3/article/viewFile/16/22.

Garzón, R. (2015). Políticas públicas de inclusión de las tecnologías de información y comunicación en la educación superior mexicana. Revista de pedagogía, 35(97), 92-107. Recovered from http://web.b.ebscohost.com/ehost/pdfviewer/pdfviewer?vid=8\&sid=0bcd9bb4-f07d-4adfb6ac-385b4cef50ba\%40sessionmgr120.

George, D., \& Mallery, P. (2003). A Simple Guide and Reference. Fourth Edition (11.0 update). Answers to Selected Exercises (4th Edition). Boston: Allyn \& Bacon. Recovered from https://wps.ablongman.com/wps/media/objects/385/394732/george4answers.pdf.

Gimeno, M. (2006). Las tecnologías de información y comunicación en las Pymes y otros avatares. Economía industrial(360), 77-92. Recovered from https://dialnet.unirioja.es/servlet/articulo?codigo=2080048.

Golding,P., Donaldson, O., Tennat, V. \& Black, K. (2008). An Analysis of Factor Affecting the Adoption og ICT By MSMEs in Rural and Urban Jamaica. Aid Electroonic Library. Recovered from https://aisel.aisnet.org/cgi/viewcontent.cgi?article=1064\&context=ecis2008.

Greene, W. H. (2003). Econometric Analysis. New York: Prentice-Hall.

Guenaga, M. L., Barbier, A. \& Eguiluz, A. (2007). La accesibilidad y las tecnologías en la información y la comunicación. TRANS(II), 155-169. Recovered from http://www.revistas.uma.es/index.php/trans/article/view/3104.

Gujarati, D. \& Porter, D. (2010). Econometría, 5 ed. ed., México: McGraw-Hill.

Gupta, K. (2007). Empowerment: A Comparative Study. The Icfai University Press, 17.

Gupta, S. K. \& Gupta, S. (2012). Potential of employee empowerment in the corporate world. International Journal of Research in IT \& Management, 2(1).

Hair, J. F., Black, W. C., Babin, B. J., \& Anderson, R. E. (2014). Multivariate data Analysis. England: Pearson Education Limited, seventh Edition ed.

Kotelnikov, V. (2007). Small and Medium Enterprises and ICT. United Nations Development Programme - Asia-Pacific Development Information Programme (UNDP-APDIP) and 
Asian and Pacific Training Centre for Information and Communication Technology for Development. Recovered from

https://www.google.com/url? sa=t\&rct=j\&q=\&esrc=s\&source=web\&cd=1\&ved=2ahUKEw j2hLjmwdzfAhUJ2qwKHSv_AeAQFjAAegQIChAC\&url=http\%3A\%2F\%2Fwww.unapcic t.org\%2Fecohub\%2Fresources\%2Fsmall-and-medium-enterprises-andict\%2Fat_download\%2Fattachment1\&usg=AOvVaw07SpxyqCY.

Liden, R. C., Wayne, S. J. \& Sparrowe, R. T. (2000). An examination of the mediating role of psychological empowerment on the relations between the job, interpersonal relationships, and work outcomes. Journal of Applied Psychology, 85(3), 407-416. Recovered from http://psycnet.apa.org/record/2000-15828-007.

Mallak, L. \& Kurstedt, H. (Noviembre-Diciembre ,de 1996). Understanding and using empowerment to change organizational culture. Industrial Management. Recovered from https://www.questia.com/magazine/1P3-10622390/understanding-and-usingempowerment-to-change-organizational.

MGaleeva, G (2019). Modeling the process of attracting foreign investment in the Russian economy. Journal of Physics: Conference Series. 1391: 012154. doi:10.1088/17426596/1391/1/012154.

Martelo, R. J, Jiménez, I. A, \& Jaimes, J. D.C. (2017). Accesibilidad e Integración Digital: Elementos Clave para un Programa de Formación de Empresarios en Empoderamiento Digital. Información tecnológica, 28(6), 81-94. https://dx.doi.org/10.4067/S071807642017000600010.

Matthews, R. A., Diaz, W. M. \& Cole, S. G. (2003). The organizational empowerment scale. Personnel Review, 32(3), 297-318. Recovered from https://www.emeraldinsight.com/doi/full/10.1108/00483480310467624.

Martín, F., Cristescu, M., Ciovica, L. \& Ciovica, L. (2012). E-Readiness of Romanian SMEs. Anale. Seria Ştiinţe Economic, 18, 150-155.

Mendoza, J. (2018). Las Tecnologías de información y comunicación un gran reto para las PYMES del distrito de Changuinola, República de Panamá. Revista de I+D Tecnológico, 14(2), 49-56. Recovered from http://revistas.utp.ac.pa/index.php/idtecnologico/article/view/2073.

Miquilena, D. \& Portillo, I. M. (2010). Empowerment como estrategia empresarial en organizaciones sociales. SINNCO.

Mohitmafi, K. \& Hanafizadeh, P. (2016). A selection framework of the e-business model by assessing organizational e-readiness. 2016 IEEE International Conference on Industrial Engineering and Engineering Management (págs. 24-28). Bali, Indonesia: Publisher \& Sponsor: IEEE. Recovered from https://ieeexplore.ieee.org/abstract/document/7798181.

Molla, A. \& Licker, P. S. (2005). eCommerce adoption in developing countries: a model and instrument. Information \& Management, 42, 877-899. doi: 10.1016/j.im.2004.09.002. 
Muduli, A. (2017). Workforce agility: Examining the role of organizational practices and psychological empowerment. Global Business \& Organizational Excellence, 36(5), 46-56. Recovered from http://web.b.ebscohost.com/ehost/pdfviewer/pdfviewer?vid=2\&sid=6036284c-3943-4e29ac68-af0025f9b95d\%40sessionmgr120.

Orgambídez-Ramos, A., Moura, D. \& de Almeida, H. (2017). Estrés de rol y empowerment psicológico como antecedentes de la satisfacción laboral. Revista de Psicología, 35(1), 257278. Recovered from https://www.redalyc.org/comocitar.oa?id=337849319010.

Oshagbemi, T. (2003). Personal correlates of job satisfaction: empirical evidence from UK universities. International Journal of Social Economics, 30(12), 1210-1232.

Page, N. \& Czuba, C. (2011). Empowerment: What Is It? Extension Journal, Inc., 49(5). Recovered from https://www.joe.org/joe/1999october/comm1.php/php.

Palacios, J., Flores-Roux, E. \& García, A. (2013). Diagnóstico del sector TIC en México Conectividad e inclusión social para la mejora de la productividad y el crecimiento económico. México: Banco Interamericano de Desarrollo.

Palomo, M., Hernández, V., Pedraza, E. \& Bolaños, E. (2009). Formación de recursos humanos en gestión tecnológica. Ingenierías, XII(45), 37-45. Recovered from http://ingenierias.uanl.mx/45/45_Formacion.pdf.

Pedraza, N. A., Sánchez, A. \& García, F. (2005). La importancia de la adopción de TIC en las Pymes mexicanas: Una Propuesta metodológica. Revista académica de economía, 66 (1).

Penz, D., Costa, B., Nascimento, S. \& Rossetto, C. R. (2017). The influence of technology readiness index in entrepreneurial orientation: a study with Brazilian entrepreneurs in the United States of America. International Journal of Innovation, 5(1), 66-76. Recovered from https://www.redalyc.org/articulo.oa?id=499154043005.

Pérez, L. \& Guerrero, A. (2012). Empowerment, un analisis desde el perfil demográfico. Panorama Administrativo, 6 (11). Recovered from http://132.248.9.34/hevila/Panoramaadministrativo/2012/vol6/no11/1.pdf.

Pérez, L., Ramírez, N. C. \& Topete, E. (2017). Estudio comparativo del uso de tecnologías de información y comunicación en pymes y grandes empresas. RAITES (Panorama Administrativo), 3(7), 49-74. Recovered from http://itcelaya.edu.mx/ojs/index.php/raites/article/view/991/825.

Princely, I. (2005). Measuring Africa's e-readiness in the global networked economy: A ninecountry data analysis. International Journal of Education and Development using ICT, 1(1), 53-71. Recovered from https://www.learntechlib.org/p/42300/.

Proméxico. (2014). Proméxico. Recovered from http://www.promexico.gob.mx/negociosinternacionales/pymes-eslabon-fundamental-para-el-crecimiento-en-mexico.html.

Quintana, L. y M. A. Mendoza (2008). Econometría Básica. Modelos y aplicaciones a la economía mexicana. Plaza y Valdés Editores, México. 
Qureshi, Q. A., Qureshi, N. A., Chishti, K. A., Kundi, G. M., Khan, S., Akhtar, R. \& Khan, I. (2014). E-readiness: a critical factor for successful implementation of ehealth projects in developing countries like Pakistan. Gomal University Journal of Research, 30(2), 77-86. Recovered from http://search.ebscohost.com/login.aspx?direct=true \&db=a9h\&AN=101525212\&site=ehostlive.

Ramsey, J. (1969). Test for Specification Errors in Classical Linear Least Square Regression Analysis. Journal of the Royal Statistical Society, Series B, 31(2), 350-371.

Rico, J., Peinado, Á., Salvador, M. R. \& González, F. (2016). Empowerment, satisfacción laboral e identificación organizacional en funcionarios andaluces. Monográfico de Psicología y Salud, 5(2), 33-39. Recovered from http://digibug.ugr.es/handle/10481/41431.

Ríos, M. (2014). Análiis de la preparación tecnológica en las Pymes. Revista Internacional Administración y Finanzas, 7(7), 1-20. Recovered from https://papers.ssrn.com/sol3/papers.cfm?abstract_id=2499675.

Ríos, M. (2016). Diagnóstico de la preparación tecnológica, un análisis a partir de los sectores de actividad económica en el estado de Guanajuato. En M. Ríos, Preparación tecnológica en las pymes. Un análisis comparativo a nivel regional entre México y España (págs. 1164). México: Pearson.

Ríos, M., Ferrer, J. \& Contreras, R. (2012). Hacia un modelo de medición del nivel de preparación tecnológica en las pymes. $R I G C, X(20), 1-20$. Recovered from https://www.researchgate.net/publication/257931628_hacia_un_modelo_de_medicion_del_ nivel_de_preparacion_tecnologica_en_las_pymes.

Ríos, M. M. (2017). Diagnóstico de las Tecnologías de información y la comunicación como herramienta de apoyo en la habilitación de las capacidades tecnológicas del clúster automotriz en la región Centro-norte. In Coord. López, Molina, Contreras, Ríos \& López (2017). Capacidades Tecnológicas: Impacto en la competitividad empresarial (pp. 209125). Ed. Pearson, México.

Ríos-Manríquez, M. (2019). Entrepreneur Woman and the Information and communication technologieses for Business Management Improvement. In Challenges and opportunities (103-130). IGI Global. Recovered from https://www.igi-global.com/chapter/entrepreneurwoman-and-the-information-and-communication-technologies-for-business-managementimprovement/215192.

Ríos, M., Téllez, M. d. \& Ferrer, J. (mayo-agosto de 2010). El empowerment como predictor del compromiso organizacional. Contaduría y Administración, 231. Recovered from www.redalyc.org/pdf/395/39512458006.pdf.

Rohayani, H., Kurniabudi \& Sharipuddin. (2015). A literature review: readiness factors to measuring e-learning readiness in higher education. Procedia Computer Science, 59(2015), 230-234. Recovered from https://doi.org/10.1016/j.procs.2015.07.564. 
Santiago, J. M. (2014). El impacto de la virtualización y el rol de la preparación tecnológica sobre la efectividad de la tecnología de información en la mediana empresa. PhD Thesis. Universidad de Turabo, Gurabo: Puerto Rico.

Sang, C. \& Wan, W. (2010). Readiness of Malaysian human resource professionals to be a strategic partner. Intangible Capital, 6 (1), 26-50. Recovered from https://www.redalyc.org/articulo.oa?id=54912883002.

Seirert, S. E., Silvert, S. R. \& Randolph, W. A. (2004). Taking empowerment to the next level: A multiple-level model of empowerment, performance, and satisfaction. Academy of Management Journal, 47(3), 332-349. Recovered from https://journals.aom.org/doi/abs/10.5465/20159585.

Silva , C. \& Loreto Martínez, M. (2004). Empoderamiento: proceso, nivel y contexto. Psykhe, $13(2)$.

Slusarczyk, M., Pozo, J. M. \& Perurena, L. (2015). Estudio de la aplicación de las TIC en las pymes. 3C Empresa, 4(1), 69-87. Recovered from http://ojs.3ciencias.com/index.php/3cempresa/article/view/235.

Spreitzer, G. M. (1995).Psychological empowerment in the workplace: dimensions measurement and validation. Academy of management journal, 38(5), 24. Recovered from https://www.jstor.org/stable/256865?seq=1\#page_scan_tab_contents.

Spreitzer, G. M. (1996). Social structural characteristics of psychological empowerment. Academy of management journal, 39(2), 483-504.

Srivastava, S. \& Madan, P. (2018). A Measure for Employee Empowerment in Indian Work Setting. Indian Journal of Industrial Relations, 54-2, 296-308. Recovered from http://web.b.ebscohost.com/ehost/detail/detail?vid=5\&sid=0673be9b-0232-41a1-9ea1a91e9111832f\%40sessionmgr104\&bdata=JnNpdGU9ZWhvc3QtbGl2ZQ\%3d\%3d\#AN=13 $3174386 \& \mathrm{db}=$ bth.

Srividya, P. (2016). A study on impact of employee empowerment and employee engagement on organizational commitment. SIES Journal of Management, 12(2), 45-54. Recovered from http://web.b.ebscohost.com/ehost/detail/detail?vid=9\&sid=0673be9b-0232-41a19ea1a91e9111832f\%40sessionmgr104\&bdata=JnNpdGU9ZWhvc3QtbGl2ZQ\%3d\%3d\#AN=12 $5094779 \& \mathrm{db}=\mathrm{bth}$.

Sulistyo, H. \& Siyamtinah. (2016). Innovation capability of SMEs through entrepreneurship, marketing capability, relational capital and empowerment. Asia Pacific Management Review, 21(4), 196-203. Recovered from http://web.b.ebscohost.com/ehost/detail/detail?vid=4\&sid=0bcd9bb4-f07d-4adf-b6ac385b4cef50ba\%40sessionmgr120\&bdata=JnNpdGU9ZWhvc3QtbGl2ZQ\%3d\%3d\#db=bth $\& \mathrm{AN}=123031240$.

Thadewald, T., \& Buning, H. (2007). Jarque-Bera Test and its Competitors for Testing Normality- A Power Comparison. Journal of Applied Statistics, 34(1), 87-105. http://dx.doi.org/10.1080/02664760600994539. 
Tiwari, M., Chakravarty, R. \& Goyal, J. (2014). Availability and Accessibility of Information Communication Technology (Ict) Among Dairy Farmers in Uttarakhand, India. IMPACT: International Journal of Research in Applied, Natural and Social Sciences, 2(7), 47-52.

Thomas, K. W. \& Velthouse, B. A. (1990). Cognitive elements of empowerment: an "interpretative" model of intrinsic task motivation. Academy of management review, 16.

Torres, E. (2011). Los conceptos de apropiación y poder en la teoría económica de Max Weber. Revista Problemas del Desarrollo, 42. Recovered from http://www.revistas.unam.mx/index.php/pde/article/view/24977.

Valencia, H. (2000). Como lograr el empowerment. Gestión en el Tercer Milenio. Recovered from

http://revistasinvestigacion.unmsm.edu.pe/index.php/administrativas/article/view/10029/91 33.

Vieira, R. \& Bins, F. (2005). Avaliação da Aplicabilidade do Technology Readiness Index (TRI) para a Adoção de Produtos e Serviços Baseados em Tecnologia. RAC - Revista de Administração Contemporânea, 9(3), 1-14. Recovered from https://www.redalyc.org/articulo.oa?id=84090307.

Yazici, B., \& Yolacan, S. (2007). A comparison of various tests of normality. Journal of Statistical Computation and Simulation, 77(2), 175-183. http://dx.doi.org/10.1080/10629360600678310.

Zhang, X. \& Bartol, K. (2010). Linking empowering leadership and employee creativity: The influence of psychological empowerment, intrinsic motivation, and creative process engagement. Academy of Management Journal(1), 107-128. Recovered from https://journals.aom.org/doi/abs/10.5465/AMJ.2010.48037118. 